\title{
Workforce Investments and Poverty Dynamics
}

\author{
David S. Kraybill and Bruce A. Weber*
}

\begin{abstract}
A dynamic economic simulation model is developed to assess the potential for a workforce investment program to reduce household poverty. The program provides income to previously unemployed individuals, but when the program is administered to large numbers of persons, the aggregate effect is to increase the supply of labor and lower wages of currently employed workers slightly. The net effect on poverty depends on the number of new workers, the responsiveness of exports to changes in costs of production, and the responsiveness of the poverty rate to wage rate changes. The model results suggest that workforce investment strategies, by themselves, have only a modest impact on the poverty rate.
\end{abstract}

\section{INTRODUCTION}

Over the past decade, the focus of policies to reduce poverty in the United States has shifted from providing cash assistance for single-mother families to supporting work activity for poor adults (usually single mothers). This transition was occasioned by the passage of the Personal Responsibility and Work Opportunity Reconciliation Act of 1996, which ended the entitlement of low-income single mothers to cash assistance, conditioned receipt of cash on work activity and imposed time limits on cash assistance. As caseloads have declined and the amount spent on cash assistance has declined, states have shifted funding to work support programs, including child care, work training, education, and retention programs (Haskins and Blank 2001). A lingering concern about the policy shift from cash assistance to work supports is that this policy shift might not actually be moving former and potential recipients and their families out of poverty (Blank 1997).

The 1996 law also devolved responsibility for designing and administering welfare programs to the states and funded state programs with a block grant in place of the matching formula funding under the previous law. The social safety net in the United States is not a single welfare program, but rather a variety of state (and in many cases, local) programs, each with its own set of incentives and regulations. This change increases the importance of analysis of workforce and social support policies at the state level: it is now necessary to analyze the impact of each state's programs on the state's particular working-age population in order to understand how welfare-related workforce programs affect earnings and poverty. How much impact are work-support policies, currently favored as the social safety net, likely to have on poverty in a particular state? What level of workforce investment would it take for the state to reduce its poverty rate to a specific target rate during a given time period? These are the questions facing policy makers in the changed policy environment introduced by welfare reform.

"The Ohio State University, Columbus, $\mathrm{OH}$; and Oregon State University, Corvallis, OR. 
Answering these questions requires an understanding of poverty and workforce dynamics and a model to assess the impact of state policy on poverty. This paper seeks to address these questions by developing a dynamic simulation model of poverty incidence that links workforce investments to workforce behavior of single-adult households, taking into account the interaction of labor and product markets. The paper begins with a discussion of poverty dynamics and dynamic simulation models. The next section of the paper outlines the structure of a poverty dynamics simulation model and operationalizes the model using Oregon economic and demographic data. The paper then outlines the evolution of workforce investment policies for the "transitional workforce" since the passage of 1996 welfare reform legislation. A fifth section presents a simulation of the impact of an expansion of job readiness programs on poverty using the Oregon model. A concluding section discusses the limitations of job readiness programs in achieving a reduction in the poverty rate.

\section{MODELING POVERTY DYNAMICS}

Contrary to popular stereotypes of long-term poverty and welfare dependence, poverty is actually quite dynamic. Using national longitudinal survey data, Gottschalk, McLanahan, and Sandfur (1994) find that nearly 60 percent of poverty spells last only one year. Many households, of course, experience repeated poverty spells. Nevertheless, Blank (1997) found that 50 percent of Americans who were poor between 1979 and 1991 were poor for three years or less out of the 13-year time period.

Poverty can change because of changes in family composition (marriage, divorce, or birth of a new child) or because of changes in income (getting or losing a job or changes in wages or hours worked). Blank (1997) found that more than 40 percent of poverty spells begin when the earnings of the household head decrease, usually due to unemployment. Similarly, more than 50 percent of the exits from poverty are associated with increases in the household's earned income. Changes in poverty status are clearly related to workforce dynamics.

Economists have attempted to model poverty dynamics and the factors that affect poverty status in a number of ways. Bartik (1993), for example, uses panel data from the Panel Survey of Income Dynamics (PSID) to develop econometric models of the impact of local labor demand on poverty. One set of probit models for both males and females estimates the probability that individuals who are initially poor will escape from poverty. Another set of probit models estimates the probability that individuals who are initially not poor will enter poverty. His results suggest that local economic growth helps both males and females escape poverty and helps prevent their falling into poverty.

Bane and Ellwood (1986) also used the PSID to study the dynamics of poverty by estimating factors affecting the length of poverty spells-the length of time a household's income is below the poverty line. Their analysis of the poverty exit rate hazard (the probability that a household will exit poverty given the 
length of time that it has been in poverty) between 1970 and 1981 established that the longer a family is in poverty the less likely it is to exit, and that this probability differs across demographic groups and is responsive to economic growth. One of the most interesting conclusions of their analysis was that, although many who enter poverty are poor for only a short time, most who are poor at any given time are in the midst of a long poverty spell. Stevens (1994) updated the Bane-Ellwood analysis to 1987 and expanded its scope to examine multiple poverty spells (by examining re-entry hazard as well as exit hazard). In a subsequent paper, Stevens (1999) established that failing to account for multiple spells leads to serious underestimation of the persistence of poverty.

These econometric approaches to modeling poverty dynamics have permitted significant advances in the understanding of demographic forces affecting exit from and entry into poverty, and of the impact of economic growth and business cycles on poverty dynamics. Econometric methods have not, however, been applied to the task of estimating the impact of public policies on poverty. Indeed, they are not well suited to this task for at least two reasons. First, even if one were to attempt to introduce policy variables, most econometric models do not easily allow inferences about the aspects of a particular program that might affect changes in poverty status. Secondly, econometric models do not capture feedback effects of behavioral responses to policy changes in an explicit manner.

In this paper, we introduce a modeling approach-a dynamic simulation model - that overcomes both of these limitations. The dynamic simulation model developed below both links specific policy actions to labor market behavior that ends up affecting poverty, and allows the individual behavioral responses to policy to have an effect on market-determined variables, such as wage rates, that in turn induce further behavioral responses that change poverty outcomes. A previous dynamic simulation model of poverty outcomes (Davis and Weber 1998) had links between poverty outcomes and behavior but emphasized the impact of policy on changes in family composition and neglected interactions in the local labor market. This paper improves on the previous dynamic simulation work by developing a model that emphasizes the dynamics of the labor market.

\section{A STATE-LEVEL POVERTY DYNAMICS SIMULATION MODEL}

Current poverty alleviation policies are aimed primarily at increasing labor force participation and raising workers' wages. We develop a four-module dynamic simulation model linking individuals, households, labor markets, and industries for simulating the effects of these policies.

Dynamic simulation models are systems of equations that describe change over time. Given a set of initial conditions and assumed behavioral parameters, these models trace changes in key variables over time and allow analysis of the dynamic implications of changes in external conditions. The process of building a model involves specifying functional relationships, initial conditions, and parameters. The model is then validated by comparing model predictions with historical data. Changes are made in parameters and input variables to yield better 
"predictions" of historical values of key variables (Ruth and Hannon 1997). A model that "predicts" historical outcomes satisfactorily can be used as a baseline against which to compare scenarios based on alternative inputs and parameters.

FIGURE 1

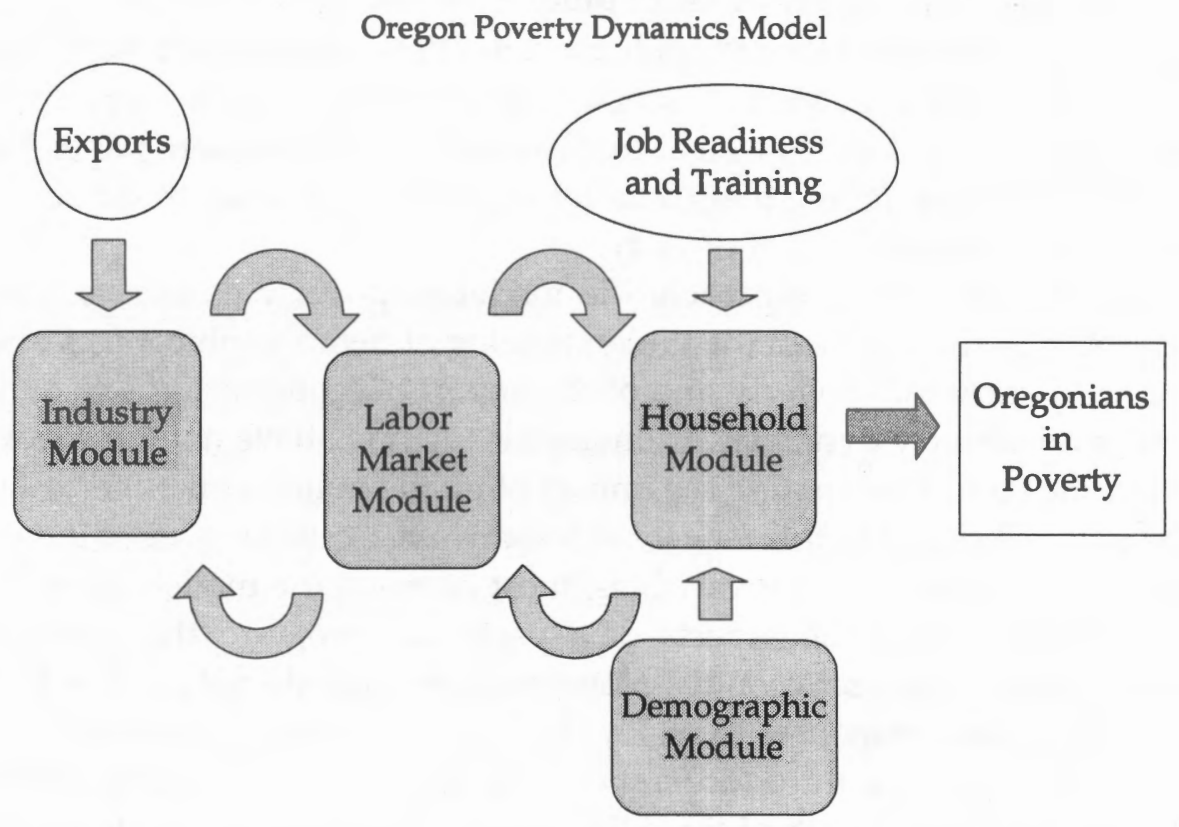

The overall structure of the model is shown in Figure $1 .{ }^{1}$ Final demand (export sales to purchasers outside the state, household consumption, government purchases, and investment) drives production in the industry module. Industries hire workers from the labor module based on wages determined by the interaction of the household supply of labor and industry demand for labor. The demand for labor is a function of the wage rate, and the two categories of labor are substitutes, so that a fall (rise) in the low-skill wage relative to the high-skill wage results in relatively more (fewer) low-skill workers being hired. The demographic module supplies people to the household module through natural growth in population (births minus deaths) and through net migration, which depends in part on wages in the state relative to wages elsewhere. The household module in turn supplies workers to high-skill and low-skill labor markets in the labor market module. Increases in labor supply from the household module lower wages, reducing the costs of production and hence product prices, which boosts exports. The increase in exports stimulates demand for labor, which puts upward pressure on wages and makes the state more attractive as a migration destination but less attractive as a business location. The poverty rate is also affected by wages. Increases in the low-skill wage reduce the probability of being poor and reduce the poverty rate.

\footnotetext{
${ }^{1}$ The model was developed using Stella, a software package that solves systems of difference equations linked to a graphical user interface (High Performance Systems 1997). In the development phase, we utilized the graphical user interface to demonstrate the emerging model to state agency personnel and to elicit their suggestions on the modeling of labor force policies.
} 
There are a number of ways that policies to reduce poverty could be introduced into the model. For example, policies aimed at reducing industry costs and thus increasing demand for workers could be built into the industry module, or policies to increase the minimum wage could be introduced in the labor market module. In this paper, we introduce a job readiness program aimed at increasing the availability of workers in the household module. By increasing the probability that currently unemployed persons will successfully enter the labor market, labor force policies can affect the poverty rate of the state.

\section{AN OREGON EXAMPLE}

The model structure sketched above was developed into an operational dynamic simulation model using Oregon data.

\section{Demographic Module}

FIGURE 2



There are seven age cohorts in the demographic module (Figure 2): under age 1, ages 1-4, ages 5-17, ages 18-24, ages 25-44, ages 45-64, and age 65 and over. Births are determined by the number of women age 18 to 44 and the fertility rate. Infants that survive the first year enter a "conveyor belt" that transports them to the 1-4 year category, where they remain for four years. At the end of this period, they are moved to the 5-17 year category, where they remain for 13 years. They then are moved to the next category, and the aging process continues in this manner. Within each age category, annual migration rates and death rates are applied and the stock of persons in that category is adjusted accordingly. The demographic module was constructed using data from the 1996 Oregon Population Survey $^{2}$ and from population forecasts by the state of Oregon (Oregon Progress Board 2000; Office of Economic Analysis 2000; Vaidya 1997).

${ }^{2}$ The Oregon Population Survey is a biennial survey conducted by the state of Oregon to learn about the socioeconomic characteristics of the state's population (Vaidya 1997; Oregon Progress Board 2000). Telephone interviews were conducted with 5,249 Oregon households by Bardsley and Neidhart Inc., a survey research firm in Portland, Oregon. 


\section{Household Module}

Since poverty is defined for households and not individuals, it is necessary to group individuals into households to model poverty dynamics. There are nine household groups in the model. These household groups receive people from the demographic module when they reach their 25th year and are grouped into households that supply adult workers to the labor market module. When household heads turn 65, the household module retires household members from the labor market, except for a small percentage of households in which retirement is delayed.

Households are classified into nine types depending on whether there are one (single) or two (couple) adult householders and on the workforce status of the respondent and (in couple households) the respondent's spouse or partner. The household module was constructed using data from the 1996 Oregon Population Survey. The Oregon Population Survey has 13 occupational categories that we classified as either high-income occupations or low-income occupations based on whether median annual earnings were above or below $\$ 22,500$ :

- High-income occupations: managerial, owner (classified as high-income even though median earning was $\$ 22,000$ because the family poverty rate for owners was very low), professional, craftsman, machine operator, fishing and forestry, and protective service.

- Low-income occupations: wholesale/retail, clerical, laborer, agriculture, personal services, household services.

Using this categorization of occupations, nine household types were created: Single-Adult Household (40 percent of households)

- HH1: adult does not report being employed or self-employed (17 percent of households);

- HH2: adult is employed in a low-income occupation (11 percent of households);

- HH3: adult is employed in a high-income occupation (12 percent of households).

Couple Households ( 60 percent of households)

- HH4: neither adult reports being employed or self-employed (12 percent of households);

- HH5: one adult is employed in a low-income occupation and the other does not report being employed or self-employed (7 percent of households);

- HH6: one adult is employed in a high-income occupation and the other does not report being employed or self-employed (10 percent of households);

- HH7: both adults are employed in low-income occupations (5 percent of households);

- HH8: one adult is employed in a high-income occupation and the other is employed in a low-income occupation (17 percent of households);

- HH9: both adults are employed in high-income occupations (10 percent of households). 
The Oregon Population Survey defines a household the same way as the U.S. Census defines it: a group of people who live and sleep in the same housing unit. Households in the simulation model are conduits through which workers are supplied to the labor force module. In order for households to supply the proper number of workers, it is necessary to take into account three realities. First, many adults in Oregon households, particularly the single-adult households, are retired. Almost one quarter ( 24 percent) of Oregon households are headed by a person over 65 years of age. Second, many households have workers besides the respondent and spouse or partner. Indeed, 12 percent of the employed workforce consists of nonspouse adult relatives living in households and 4 percent of the employed workforce is nonrelatives (boarders, roommates, housemates) living in households. Third, there are more jobs than workers because many workers hold more than one job. In 1996, 15 percent of the respondents in the Oregon Population Survey reported holding more than one job. The average respondent held 1.18 jobs. Each high-income worker held an average of 1.16 jobs. Each low-income worker held an average of 1.20 jobs. Our labor ("job") supply estimate in Table 1 is based on the assumption that multiple job holding occurred at these rates for all working adults. Table 1 shows the number of households in each household category and the number of jobs held by workers in each household type.

TABLE 1

Households, Jobs, and Poverty Rate by Household Type, 1996

\begin{tabular}{lcccrr}
\hline $\begin{array}{l}\text { Household } \\
\text { Type }\end{array}$ & $\begin{array}{c}\text { Number of } \\
\text { Households }\end{array}$ & $\begin{array}{c}\text { Percent of } \\
\text { Households }\end{array}$ & $\begin{array}{c}\text { Number of } \\
\text { Jobs }\end{array}$ & $\begin{array}{c}\text { Percent of } \\
\text { Jobs }\end{array}$ & $\begin{array}{r}\begin{array}{c}\text { Poverty } \\
\text { Rate }\end{array} \\
\hline \text { HH1 }\end{array}$ \\
HH2 & 208,887 & 17 & 37,330 & 2 & 35.4 \\
HH3 & 135,818 & 11 & 206,242 & 12 & 21.2 \\
HH4 & 150,943 & 12 & 230,296 & 13 & 9.8 \\
HH5 & 143,479 & 12 & 14,655 & 1 & 16.2 \\
HH6 & 81,341 & 7 & 113,936 & 7 & 16.1 \\
HH7 & 122,712 & 10 & 159,198 & 9 & 9.4 \\
HH8 & 56,961 & 5 & 148,103 & 9 & 8.3 \\
HH9 & 203,386 & 17 & 526,916 & 30 & 3.6 \\
Total & 118,946 & 10 & 306,124 & 18 & 2.1 \\
\hline
\end{tabular}

Source: Oregon Progress Board, 1996 Oregon Population Survey.

\section{Labor Market Module}

Separate labor markets are specified for low-skill and high-skill labor in the model. Households supply workers to the labor force in each of the two labor markets and industries hire labor. Wages are determined by the interaction of supply and demand for labor. The difference between the quantity of labor supplied and the quantity demanded is unemployment. The rate of unemployment influences the regional wage rate, based on a wage curve relationship (Blanchflower and Oswald 1996; Deller and Tsai 1998) estimated by the authors for Oregon. Wages adjust to the unemployment rate with a one-period lag. The resulting wage rate then affects the number of workers hired by firms. 
Data on employment were obtained from Oregon input-output tables generated by the 1996 IMPLAN regional economic accounts generator (MIG, Inc. 1996). ${ }^{3}$ Employment estimates in IMPLAN are derived from the Regional Economic Information System (U.S. Department of Commerce 1996). The IMPLAN employment estimates were allocated to low- and high-skill labor markets based on occupational data obtained from the Oregon Population Survey. The wage is $\$ 17,000$ in the low-skill labor market and $\$ 38,000$ in the high-skill labor market (1996 dollars). Labor supply estimates from the Oregon Population Survey were adjusted to be consistent with the IMPLAN-based employment estimates and an unemployment rate of 4 percent in the high-skill labor market and 8 percent in the low-skill labor market.

Interindustry Module

FIGURE 3

Interindustry Module

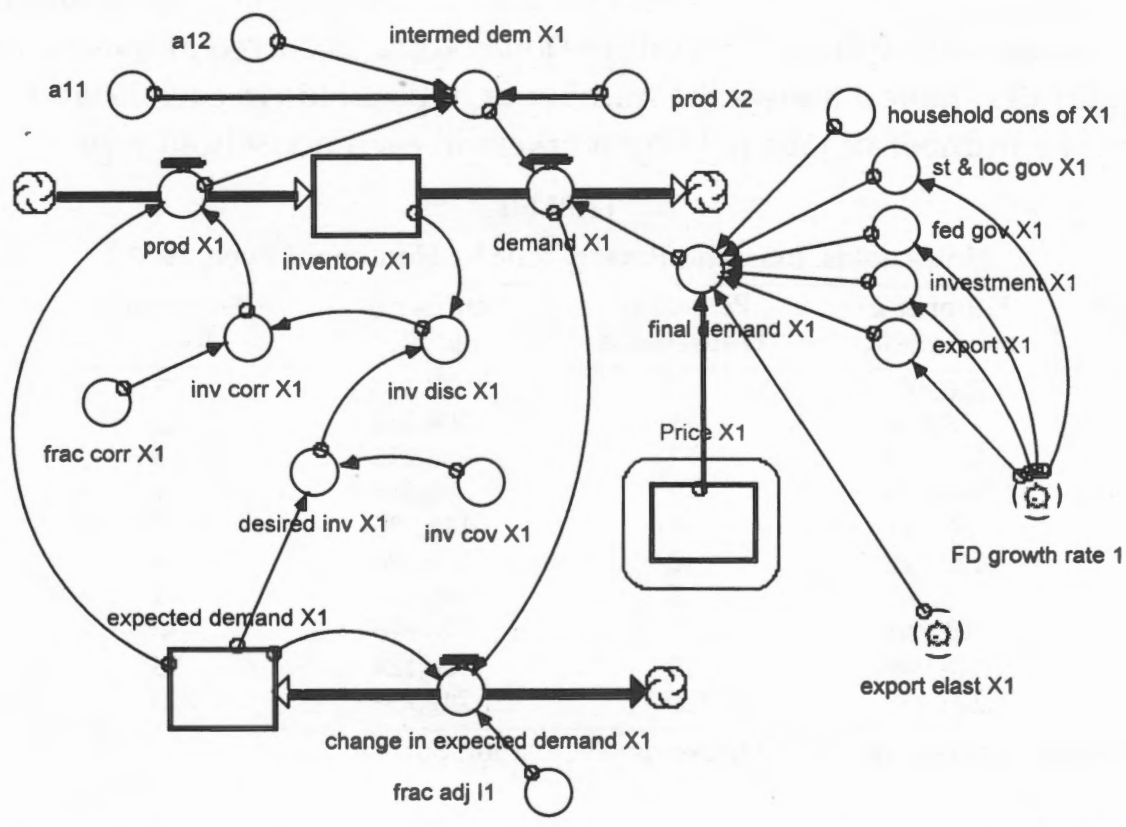

Production is estimated using a dynamic interindustry model (Figure 3). The foundation of the model is a material-balance equation that requires production to equal intermediate and final demand. Data on production and inputs is from the 1996 IMPLAN database. The structure of the model, however, is dynamic and firms adjust both inputs and outputs to changes in wages and output prices, which are flexible in this model. Inventory, a component of final demand, adjusts to accommodate excess demand or excess supply in each period. The change in inventory is a stock-adjustment process of recursive expectations in which the

${ }^{3}$ IMPLAN is both a regional social accounts generator and a static input-output model. In this study, we used only the IMPLAN SAM, not the IMPLAN input-output model. Instead, we created a dynamic input-output model in Stella, a computer simulation software package and introduced the SAM data into this environment. 
decisions of one period are linked to the decisions of the next period. Following a shock to final demand, production initially lags demand but eventually catches up as the economy converges to a long-run stable growth path. Household spending is a constant share of labor income, which is determined endogenously in the labor market. Other categories of final demand are state and local government expenditures, federal government expenditures, gross private investment expenditures, and exports. A balanced budget is assumed for state and local government, whose spending is endogenously determined by the level of revenue. Gross private investment and federal spending are assumed to grow at an exogenous rate roughly equal to Oregon's growth rate over the period 1990-1996. Exports in the model deviate from an underlying exogenous rate of growth in response to changes in the cost of production in Oregon. If labor costs rise, the price of Oregon's output rises and the rate of export growth drops. If Oregon production costs fall, the rate of export growth rises.

In addition to purchasing goods and services, the state government spends its balanced budget on labor force preparation services in the model. An ad valorem industry tax instrument is used to estimate the corporate profit tax and the property tax (Oregon does not have a sales tax). A personal income tax is calculated, using information from the Oregon Legislative Revenue Office, on the effective tax rates for workers earning the average wage for each of the two labor markets.

\section{Model Parameters}

Stock and flow responses in the model are governed by a number of elasticities and other parameters. Table 2 identifies the most important of these, indicates their values, and gives the rationale and source of the data used to estimate them. The assumed annual growth rate of exports is estimated as a simple average of the annual rate of growth of real gross domestic product for the United States over the period 1996-1998. The price elasticity of final demand for traded goods is a "best guess" since no econometric estimates of price elasticities for traded goods are available at the subnational level in the United States. However, international export elasticities are typically in the range of 1 to 4, with a midpoint of approximately 2.5 (Stern, Francis, and Schumacher 1976). We use a price elasticity of exports of 5.0 for Oregon, roughly twice the midpoint of the range of national export elasticities on the grounds that a state is a small open economy and its price elasticity of exports is likely to be higher than that of the nation. Migration elasticities with respect to high- and low-skill labor are calibrated so that the model achieves a migration flow from 1996 to 2000 that corresponds to the migration flows projected by the state of Oregon. The elasticity of high- and lowskill annual earnings with respect to the unemployment rate is estimated to be -0.04 , based on an econometric wage curve relationship estimated for Oregon over the period 1978-1997. The elasticity of the poverty rate with respect to income is set at a low value, consistent with the findings of Blank (1997) that economic growth in the period 1980-2000 contributed relatively little to reduction in poverty. 
TABLE 2

Selected Parameters in the Poverty Dynamics Model

\begin{tabular}{lcl}
\hline Parameter* & $\begin{array}{c}\text { Value of } \\
\text { Parameter }\end{array}$ & Rationale \\
\hline $\begin{array}{l}\text { Trend growth rate of exports of traded } \\
\text { goods }\end{array}$ & $4.7 \%$ & $\begin{array}{l}\text { Growth rate of U.S. GDP during the period } \\
1996-1998 .\end{array}$
\end{tabular}
goods

Price elasticity of final demand for traded goods

Net migration elasticity with respect to high-skill annual income

Net migration elasticity with respect to low-skill annual income

Elasticity of high-skill annual earnings with respect to unemployment rate

Elasticity of low-skill annual earnings with respect to unemployment rate

Elasticity of poverty rate with respect to income
This is a "guesstimate." A high value was selected because markets for traded goods tend to be highly competitive.

Set to achieve a migration flow that corresponds in the model baseline to migration flows projected by the state of Oregon.

10 Set to achieve a migration flow that corresponds in the model baseline to migration flows projected by the state of Oregon.

Based on authors' econometric estmates of the Oregon wage curve relationship over the period 1978-1997

-0.04 Based on authors' econometric estimates of the Oregon wage curve relationship over the period 1978-1997.

-0.1 Blank (1997, p. 52) has found that economic growth in the 1980s and 1990s did not produce substantial declines in poverty.

*The first parameter above is a rate of growth. All other parameters in the table are elasticities.

\section{Moving Out of Poverty}

The poverty rate changes in the model when adults make job changes that move them from one household category to another (by getting a job, if not working; by moving from a low-wage job to a high-wage job, if already working) or when the Oregon average wage for low-wage jobs increases. If the adult in a single, unemployed adult household ( $\mathrm{HH} 1$ ) gets a low-wage job, for example, the household moves from the $\mathrm{HH} 1$ household category to the $\mathrm{HH} 2$ category. The probability of being poor differs among household types. Therefore, moving from one household type to another changes the probability of being poor. The overall poverty rate in each period is calculated as the average of the poverty rates of each household type, weighted by the number of households of that type during that period. Table 1 shows the poverty rate for each of the nine household types. The poverty rate is also affected by changes in the average wage of low-skill workers: an increase in the low-skill wage reduces the overall poverty rate. 


\section{Baseline Scenario}

The baseline ("without") scenario is established by simulating the Oregon economy over an 11-year period (1996-2006). Model parameters were adjusted to approximately reproduce the 10-year official forecast of population in Oregon. The population forecast in Table 3 is the September 2000 forecast. The model predicts a 12.1 percent increase in population, compared to the official forecast of a 12.2 percent increase over the 1996-2006 period. The model also predicts a 21.4 percent increase in employment, compared to a 21.8 percent increase in the official forecast. The baseline simulation has the poverty rate remaining steady at about 11.4 percent over this period. ${ }^{4}$

TABLE 3

Model Baseline and Official State Forecast

\begin{tabular}{|c|c|c|c|c|c|c|c|}
\hline \multirow[t]{2}{*}{ Year } & \multirow[b]{2}{*}{$\begin{array}{l}\text { Model } \\
\text { Baseline }\end{array}$} & \multirow{2}{*}{$\begin{array}{c}\text { Population } \\
\text { Official } \\
\text { Forecast }\end{array}$} & \multicolumn{2}{|c|}{$\begin{array}{l}\text { Total Employment } \\
\text { Model Baseline }\end{array}$} & \multicolumn{2}{|c|}{$\begin{array}{l}\text { Nonagricultural } \\
\text { Employment } \\
\text { Official Forecast* }\end{array}$} & \multirow{2}{*}{$\begin{array}{c}\begin{array}{c}\text { Poverty } \\
\text { Rate }\end{array} \\
\text { Model } \\
\text { Baseline }\end{array}$} \\
\hline & & & Level & $\begin{array}{c}\% \\
\text { Change }\end{array}$ & Level & $\begin{array}{c}\% \\
\text { Change }\end{array}$ & \\
\hline 1996 & $3,299,331$ & $3,181,000$ & $1,895,053$ & - & $1,474,700$ & - & 11.4 \\
\hline 1997 & $3,338,213$ & $3,217,000$ & $1,956,442$ & 3.2 & $1,526,400$ & 3.5 & 11.4 \\
\hline 1998 & $3,372,983$ & $3,267,550$ & $2,042,587$ & 4.4 & $1,551,800$ & 1.7 & 11.4 \\
\hline 1999 & $3,425,197$ & $3,300,800$ & $2,048,352$ & 0.3 & $1,572,400$ & 1.3 & 11.4 \\
\hline 2000 & $3,459,179$ & $3,339,000$ & $2,060,412$ & 0.6 & $1,599,900$ & 1.7 & 11.4 \\
\hline 2001 & $3,495,797$ & $3,378,000$ & $2,088,929$ & 1.4 & $1,627,400$ & 1.7 & 11.4 \\
\hline 2002 & $3,537,008$ & $3,415,000$ & $2,124,541$ & 1.7 & $1,654,000$ & 1.6 & 11.4 \\
\hline 2003 & $3,577,141$ & $3,453,000$ & $2,167,529$ & 2.0 & $1,691,600$ & 2.3 & 11.4 \\
\hline 2004 & $3,616,960$ & $3,491,000$ & $2,210,938$ & 2.0 & $1,732,900$ & 2.4 & 11.4 \\
\hline 2005 & $3,658,074$ & $3,529,000$ & $2,253,256$ & 1.9 & $1,766,400$ & 1.9 & 11.4 \\
\hline 2006 & $3,700,094$ & $3,568,000$ & $2,300,051$ & 2.1 & $1,796,600$ & 1.7 & 11.4 \\
\hline \multicolumn{8}{|l|}{ Change } \\
\hline '96-'06 & 400,763 & 387,000 & 404,998 & 21.4 & 321,900 & 21.8 & 0.0 \\
\hline
\end{tabular}

*Oregon Department of Administrative Services, Oregon Economic and Revenue Forecast, September 2000 .

\section{WORKFORCE INVESTMENT POLICY FOR THE TRANSITIONAL WORKFORCE}

During the past five years, there have been several important developments in workforce policy for the "transitional workforce" (the unemployed, underemployed, or workers in transition to new jobs). Two years after the passage

\footnotetext{
4The two best sources of state-level information on poverty in Oregon are not consistent in their estimates of poverty incidence during the 1996-1999 period. The Oregon Population Survey, described above, estimates the poverty rate in Oregon in 1997 to be 11.8 percent, and the preliminary estimate of poverty for 1999 is 10.7 percent. The Current Population Survey (CPS), which produces rolling three-year averages of poverty for each state, estimates poverty in the 1996 base year (1995-97) to be 11.5 percent, quite close to the Oregon Population Survey estimate used to establish the model baseline. The estimates for subsequent years, however, show quite different levels of poverty and quite different trends. The 1997 (1996-98) estimate of Oregon poverty is 12.8 percent and the 1998 (1997-99) estimate is 13.1 percent. These estimates are quite imprecise, however. The $90 \%$ confidence interval around the 1995-97 CPS-estimated poverty rate of 11.5 percent is 9.5 percent to 13.5 percent, a range that includes the subsequent poverty rate estimates (Center on Budget and Policy Priorities 2000). Because the one series suggests that poverty has gone up while the other series suggests it has gone down, we feel the model baseline in which the poverty rate is relatively constant can be defended.
} 
of welfare reform, Congress enacted the Workforce Investment Act (WIA) of 1998, which sought to integrate and streamline employment and training services into a comprehensive workforce investment system. With the passage of WIA, there has been considerable movement toward integration of employment services into a system that makes its basic services available to all job seekers. Indeed, WIA required the establishment of "one-stop centers," where most employment services are accessible. WIA also replaced the Job Training and Partnership Act programs that had targeted specific groups, such as the economically disadvantaged or dislocated workers, with programs that provided a broader range of services to the general public. The thrust of WIA was to broaden the range of services formerly provided to the "transitional workforce" (U.S. General Accounting Office 2000). ${ }^{5}$

With welfare reform, on the other hand, the focus of the welfare-to-work programs has moved from education and training to a "work first" strategy designed to move "transitional workers" quickly into the workforce (Haskins and Blank 2001). Studies of those who have left welfare suggest that most of them are employed at some time after they leave, many at low-wage jobs. At the same time that the states shifted toward a "work first" strategy, they also began to spend TANF funds in ways that supported those who went to work, through child care subsidies, and subsidized health care and transportation, among other things (Gais and Nathan 2001). This, plus an expansion of the Earned Income Tax Credit by the federal government, as well as some state governments, increased the probability that those who succeeded in obtaining jobs under a "work first" policy would continue to be able to work, and made it more likely that they could advance economically.

\section{IMPACT OF A “WORK FIRST" STRATEGY ON POVERTY}

The basic argument for a "work first" strategy that emphasizes job readiness programs is that work experience will lead to higher-paying jobs and eventually to movement out of poverty. Whether this is the case or not depends, among other things, on such factors as the placement and retention rates of the programs, the rate of earnings increase for work experience, the impact of the increased supply of workers on wages, and the impact of wage changes on growth in demand for the state's output. Some of these factors can be modeled in the poverty dynamics simulation model outlined above. The scenarios developed in this section of the paper are used in the poverty dynamics model to simulate the impact of expansions of job readiness programs on the percent of households in poverty in Oregon over the period 1996-2006. The scenarios focus on job-readiness services, defined as "short-term prevocational services, including development of

\footnotetext{
${ }^{5}$ While WIA did not require Temporary Assistance for Needy Families (TANF) employment-related services to be provided through these one-stop centers, most states involve TANF as a partner in the one-stop centers at the state level, and half of the states report "providing at least some TANF services on-site at a majority of their onestop centers" (U.S. General Accounting Office 2000, p. 11).
} 
learning skills, communications skills, and interviewing skills, punctuality, personal maintenance skills, and professional conduct to prepare individuals for employment or training" (Oregon Department of Community Colleges and Workforce Development 2001).

\section{Scenario Description}

There are four policy scenarios, involving differing program levels and differing assumptions about program success rates.

Scenario 1: Job Readiness at Current Program Level and Current Job Holding Rate. This scenario enrolls 20,000 unemployed workers in job readiness programs in each of years 2001 and 2002. This is roughly equal to the actual number of persons participating in job readiness programs per year in Oregon in 2001. Based on estimates by Friedlander and Burtless (1995), we assume that net job holding rates for participants in job readiness program are 25 percent in the first year after program participation and 35 percent (an increase of 10 percentage points) in the second year. These rates are net, measuring the percent of participants who hold jobs at any given time. In 2001, the first year of the Oregon state government's biennial budget, 5,000 previously unemployed persons (member of household category HH1) are assumed to acquire jobs. In 2002, the second year of the biennium, an additional 7,000 previously unemployed persons acquire jobs (5,000 individuals who participated in the program in 2002 and become employed immediately, and 2,000 individuals from the "class of 2001" who search for a year before finding employment). In 2003, an additional 2,000 program participants in the "class of 2002" acquire jobs. In total, 14,000 (net) out of the 40,000 persons who participate in job readiness programs during the 2001-2002 biennium are assumed employed by year 2003.

Scenario 2: Job Readiness at Current Program Level and 100 Percent Job Holding Rate. This scenario is the same as Scenario 1, except all program participants are assumed to acquire jobs immediately. We introduce this unrealistic assumption to test whether the current program level is adequate for achieving the state's target poverty rate even if the program success rate is at the highest possible level.

Scenario 3: Job Readiness at Maximum Program Level and Current Job Holding Rates. This scenario assumes that all single, unemployed adults of working age (members of household category HH1) in Oregon participate in the job readiness program during the 2001-2002 biennium. Half of these individuals $(42,875)$ participate in 2001 and the other half participate in 2002. Net job holding rates for participants are assumed to be the same as for Scenario $1-25$ percent in the first year after program participation and 35 percent in the second year.

Scenario 4: Job Readiness at Maximum Program Level and Doubled Job Holding Rates. This scenario is the same as Scenario 3, except the net job holding rates are assumed to be double (for example, through more effective training or monitoring). Fifty percent of program participants are now assumed to hold jobs in the first year and 70 percent (an additional 20 percentage points) in the second year. 


\section{Results}

Each of the program scenarios reduces poverty. The increase in the size of the low-skill labor force initially lowers the low-skill wage rate slightly. This reduces production costs and hence output prices of producers of traded and nontraded goods and services and stimulates final demand, which in turn stimulates the demand for both low- and high-skill labor. The increase in demand for highskill labor increases the high-skill wage rate, which lowers the unemployment rate and attracts in-migrants to the state. However, the increase in the low-skill labor force is larger than the increase in demand for low-skill labor, leading to more unemployment and wage declines in this labor market and out migration of lowskill workers. Differences across scenarios in the size of the job readiness programs and in the job retention rates of the participants lead to different outcomes across the scenarios.

Scenario 1. In 2001, the first year of the job readiness program, the poverty rate is reduced to 11.3 percent, a decrease of one-tenth of a percentage point from the baseline (see Table 4). In 2002, the second year of the program, the poverty rate falls another one-tenth percent to 11.2 percent and remains stable at this rate through year 2006.

Scenario 2. By increasing the job holding of program participants to the unrealistic rate of 100 percent while holding the job readiness program at the actual level of funding in 2001, this scenario allows us to examine whether there is any possibility of the state of Oregon achieving its target poverty rate of 10 percent with the current annual number of participants in job readiness programs. Under these assumptions, the poverty rate now drops to 11.1 percent (a threetenths of a percent drop) in 2001 and to 10.8 percent (a six-tenth of a percent drop) in 2002. Under the current level of funding, the state falls short of its target poverty goal by the end of the two-year biennium even under the most favorable program outcome (100 percent job holding by participants).

Scenario 3. If all members of household category $\mathrm{HH} 1$ participate in the job readiness program in 2001 and 2002 under the Friedlander-Burtless rate of job holding by participants, the poverty rate drops to 11.2 in 2001 and to 11.0 in 2002, remaining steady at this rate through 2006.

Scenario 4. Under the most favorable program outcome (a 100 percent job holding rate), providing job readiness training to all persons in the $\mathrm{HH} 1$ household category lowers the poverty rate to 10.5 percent by 2003 . This is a reduction of nine-tenths of a percent as compared to the baseline.

These simulation results suggest that Oregon is not likely to attain its target poverty rate of 10 percent through a job readiness program targeted at single, unemployed adults. 
TABLE 4

Simulation Results: Impacts of Workforce Policy on Poverty Rate

\begin{tabular}{|c|c|c|c|c|c|c|c|c|c|}
\hline \multirow[b]{2}{*}{ Year } & \multirow{2}{*}{$\begin{array}{c}\text { Baseline } \\
\begin{array}{c}\text { Poverty } \\
\text { Rate }\end{array}\end{array}$} & \multicolumn{2}{|c|}{ Scenario 1} & \multicolumn{2}{|c|}{ Scenario 2} & \multicolumn{2}{|c|}{ Scenario 3} & \multicolumn{2}{|c|}{ Scenario 4} \\
\hline & & $\begin{array}{c}\text { Poverty } \\
\text { Rate }\end{array}$ & Difference & $\begin{array}{c}\text { Poverty } \\
\text { Rate }\end{array}$ & Difference & $\begin{array}{c}\text { Poverty } \\
\text { Rate }\end{array}$ & Difference & $\begin{array}{c}\text { Poverty } \\
\text { Rate }\end{array}$ & Difference \\
\hline 1996 (base) & 11.4 & 11.4 & 0.0 & 11.4 & 0.0 & 11.4 & 0.0 & 11.4 & 0.0 \\
\hline 1997 (Yr. 1) & 11.4 & 11.4 & 0.0 & 11.4 & 0.0 & 11.4 & 0.0 & 11.4 & 0.0 \\
\hline 1998 (Yr. 2) & 11.4 & 11.4 & 0.0 & 11.4 & 0.0 & 11.4 & 0.0 & 11.4 & 0.0 \\
\hline 1999 (Yr. 3) & 11.4 & 11.4 & 0.0 & 11.4 & 0.0 & 11.4 & 0.0 & 11.4 & 0.0 \\
\hline 2000 (Yr. 4) & 11.4 & 11.4 & 0.0 & 11.4 & 0.0 & 11.4 & 0.0 & 11.4 & 0.0 \\
\hline 2001 (Yr. 5) & 11.4 & 11.3 & 0.1 & 11.1 & 0.3 & 11.2 & 0.1 & 11.1 & 0.3 \\
\hline $2002($ Yr. 6) & 11.4 & 11.2 & 0.2 & 10.8 & 0.6 & 11.0 & 0.4 & 10.6 & 0.7 \\
\hline 2003 Yr. 7) & 11.4 & 11.2 & 0.2 & 10.8 & 0.6 & 11.0 & 0.4 & 10.5 & 0.9 \\
\hline 2004 (Yr. 8) & 11.4 & 11.2 & 0.2 & 10.8 & 0.6 & 11.0 & 0.4 & 10.5 & 0.9 \\
\hline 2005 (Yr. 9) & 11.4 & 11.2 & $0 . \overline{2}$ & 10.8 & 0.6 & 11.0 & 0.4 & 10.5 & 0.9 \\
\hline 2006 (Yr. 10) & 11.4 & 11.2 & 0.2 & 10.9 & 0.6 & 11.0 & 0.4 & 10.6 & 0.9 \\
\hline
\end{tabular}

Scenario 1: 20,000 unemployed single persons in household type $\mathrm{HH} 1$ given job preparation training in each of years 5 and 6 . Net job acquisition rates are assumed to be 25 percent in the first year after program participation and 35 percent (an increase of 10 percent) in the second year.

Scenario 2: same as Scenario 1, except the net job acquisition rate is assumed to be 100 percent in the first year after program participation.

Scenario 3:42,875 unemployed single persons-half the HH1 households-are given job prep in each of years 5 and 6 . Net job acquisition rates are assumed to be the same as for Scenario 1 (25 percent in the first year after program participation and 35 percent in the second year).

Scenario 4: same as Scenario 3, except the net job acquisition rates are doubled (50 percent in first year after program participation and 70 percent-an increase of 20 percent-in the second year).

\section{Sensitivity Analysis}

The responsiveness of poverty to policy changes is potentially affected by a number of elasticities in the dynamic simulation model. Our sensitivity analysis focuses on parameters expected to have the largest effects on the estimated poverty rate. Three values of each of the tested parameters were used: an initial (central) value, a low value ( 50 percent of the central value), and a high value (50 percent more than the central value). Central values are reported in Table 2. The results of the sensitivity analysis are presented in Table 5. Sensitivity results are reported for Scenario 4 only since it has a larger impact on the poverty rate than the other three scenarios.

\section{TABLE 5}

Sensitivity Analysis of Selected Model Parameters

\begin{tabular}{lccc}
\hline Parameter & \multicolumn{3}{c}{ Poverty Rate in the 10th Year under Scenario 4 } \\
\hline & $\begin{array}{c}\text { For Low } \\
\text { Parameter } \\
\text { Value }\end{array}$ & $\begin{array}{c}\text { For Central } \\
\text { Parameter } \\
\text { Value }\end{array}$ & $\begin{array}{c}\text { For High } \\
\text { Parameter } \\
\text { Value }\end{array}$ \\
\hline $\begin{array}{l}\text { Traded Goods Export Elasticity } \\
\begin{array}{l}\text { Net Migration Elasticity with } \\
\text { Respect to Earnings }\end{array}\end{array}$ & 10.7 & 10.6 & 10.4 \\
$\begin{array}{l}\text { Poverty Rate Elasticity with } \\
\text { Respect to Earnings }\end{array}$ & 10.6 & 10.6 & 10.6 \\
\hline
\end{tabular}


The estimated poverty rate is moderately sensitive to the price elasticity of exports, which influences the growth of the state economy and, consequently, the demand for labor. When the central value of this parameter is used, the poverty rate declines to 10.6 percent by the 10 th year under Scenario 4 . In contrast, the low value of this elasticity generates a poverty rate estimate of 10.7 percent, while the high value generates a poverty rate estimate of 10.4 percent.

Sensitivity analysis was conducted on two other parameters. Increasing or decreasing the net migration elasticity with respect to earnings by 50 percent does not affect the poverty rate. This is not surprising because the amount of migration that occurs in any given year represents a very small percent of population and labor force.

Varying the poverty rate elasticity with respect to earnings has a very small effect on the estimated poverty rate. When the low value of the elasticity is used, the poverty rate is one-tenth of a percent lower than when the central value is used. Using the high value of the elasticity does not alter the poverty rate.

The model is relatively robust with respect to key parameters. The small effect of parameter variations on the model results does not alter the basic conclusion that the job readiness program is incapable of lowering the poverty rate to the state's target level.

\section{THE LIMITS OF A "WORK FIRST" INVESTMENT STRATEGY}

Over the past decade, social policy for needy families has shifted from cash assistance to work supports, and workforce investments under welfare reform have emphasized job placement and work-support programs (such as child care for the children of low-income workers) over education and job training. By examining ways that workforce policy might affect the behavior of firms and workers and how these behavioral responses would affect the poverty rate in the state, the dynamic simulation model developed in this paper and applied to data for the state of Oregon allows us to explore the extent to which, and the conditions under which, state workforce policy can reduce poverty.

Poverty in Oregon, as elsewhere, has proven remarkably resistant to policy fixes. After rising from 10.7 percent in 1979 to 12.4 percent in 1989, the state's poverty rate averaged around 11.5 percent during the $1990 \mathrm{~s}$. Oregon policy makers have set ambitious social, economic, and environmental goals and tracked them through a state agency known as the Oregon Progress Board. One of the critical benchmarks against which the state evaluates its social health is the poverty rate. In 2001, the Progress Board set a poverty benchmark "target" of 10 percent by the year 2010 (Oregon Progress Board 2001).

Under the assumptions built into this model, an expanded job readiness strategy that roughly doubles the size of the job readiness programs does reduce poverty over a five-year period. However, even under the most optimistic and unrealistic job placement policy scenarios, reliance on a job readiness strategy does not enable the state to meet its benchmark poverty rate of 10 percent. The 
model results suggest that if Oregon is to meet its social policy target of a 10 percent poverty rate, complementary policies that supplement income or increase the demand for the state's output will be necessary.

\section{REFERENCES}

Bane, M.J., and D. Ellwood, "Slipping Into and Out of Poverty: the Dynamics of Spells." Journal of Human Resources 21 (1986), 1-23.

Bartik, T.J. "The Effects of Local Labor Demand on Individual Labor Market Outcomes for Different Demographic Groups and the Poor." Upjohn Institute Staff Working Paper 93-23, W.E. Upjohn Institute for Employment Research, Kalamazoo, MI, September 1993.

Blanchflower, D.G., and A.J. Oswald. The Wage Curve. Boston: MIT Press, 1996.

Blank, R.M. It Takes a Nation: A New Agenda for Fighting Poverty. Princeton: Princeton University Press, 1997.

Center on Budget and Policy Priorities. "Oregon Poverty and Program Trends: Background Information." [cited 21 August 2000]. Available:

(http://www.cbpp.org)

Davis, E.E., and B.A. Weber. "Linking Policy and Outcomes: A Simulation Model of Poverty Incidence." Growth and Change 29 (1998), 423-444.

Deller, S.C., and S.T.H. Tsai. "An Examination of the Wage Curve: A Research Note." Journal of Regional Analysis and Policy 28 (1998), 3-12.

Friedlander, D., and G. Burtless. Five Years After: The Long-Term Effects of Welfareto-Work Programs. New York: Russell Sage Foundation, 1995.

Gais, T., and R. Nathan. "Status Report on the Occasion of the 5th Anniversary of the 1996 Personal Responsibility Welfare-Reform Act." Albany, N.Y.: Nelson A. Rockefeller Institute of Government, 2001.

Gottschalk, P., S. McLanahan, and G. Sandefur. "The Dynamics and Intergenerational Transmission of Poverty and Welfare Participation." In S. Danziger, G. Sandefur, and D. Weinberg (eds.) Confronting Poverty. Cambridge: Harvard University Press, 1994.

Haskins, R., and R.M. Blank. The New World of Welfare. Washington, D.C.: Brookings Institution Press, 2001.

High Performance Systems, Inc. Technical Documentation for the iThink and Stella Software. Hanover, N.H., 1997.

MIG, Inc. IMPLAN Professional: User's Guide, Analysis Guide, and Data Guide. Stillwater, Minn., 1996.

Office of Economic Analysis. "Population Forecasts, Components of Change, 1980-2005." State of Oregon. [cited 21 August 2000]. (Available:

http://www.oea.das.state.or.us/econ.htm)

Oregon Department of Community Colleges and Workforce Development. "Oregon's Workforce System." [cited 5 September 2001]. Available:

(http://www.workforce.state.or.us/provider/provider.htm) and (http://www.odccwd.state.or.us/workdev/Q\&Aweb/Default.htm) 
Oregon Progress Board. "1996 Oregon Population Survey." [cited 21 August 2000]. Available: (http://www.econ.state.or.us/opb/opsinex.htm) - The 2001 Benchmark Performance Report Achieving the Oregon Shines Vision. Salem, Ore., 2001.

Ruth, M., and B. Hannon. Modeling Dynamic Economic Systems. New York: Springer-Verlag, 1997.

Stern, R.M., J.Francis, and B.Schumacher. Price Elasticities in International Trade: An Annotated Bibliography. Toronto: Macmillan of Canada, 1976.

Stevens, A.H. "The Dynamics of Poverty Spells: Updating Bane and Ellwood." American Economic Review 84 (1994), 34-37.

. "Climbing Out of Poverty, Falling Back In: Measuring the Persistence of Poverty over Multiple Spells." Journal of Human Resources 34 (1999), 557-588.

U.S. Department of Commerce. Bureau of Economic Analysis. Regional Economic Information System. Washington, D.C., 1996.

U.S. General Accounting Office. "Workforce Investment Act: Implementation Status and the Integration of TANF Services." Testimony of C.M. Fagnoni, June 29, 2000.

Vaidya, K.L. "1996 Oregon Population Survey Summary." Oregon Office of Economic Analysis, Salem, Oregon, 1997. 